\title{
Titik Kontrol Kritis Pada Pengolahan Susu Pasteurisasi Di Koperasi Unit Desa (KUD) Dau Kabupaten Malang
}

\author{
N. D. Kristanti*, A. Warnaen, D. R. A. Daning \\ Program Studi Penyuluhan Peternakan, Sekolah Tinggi Penyuluhan Pertanian Malang
}

\begin{abstract}
ABSTRAK
Penelitian tentang Titik Kontrol Kritis pada Pengolahan Susu Pasteurisasi di Koperasi Unit Desa Dau Kabupaten Malang bertujuan untuk menganalisis titik kontrol kritis pada pengolahan susu pasteurisasi dengan menggunakan decision tree di Koperasi Unit Desa Dau. Metode penelitian yang digunakan adalah metode deskriptif kuantitatif dengan pendekatan penelitian survei. Populasi dan sampel penelitian adalah para petugas di pos penampungan, pengemudi kendaraan tangki armada, petugas di tangki transit, petugas pada pengolahan susu pasteurisasi dan petugas sanitasi di KUD Dau, jumlah sampel sasaran penelitian adalah 22 orang. Analisis data yang digunakan adalah analisis statistik deskriptif. Hasil penelitian Titik Kontrol Kritis Proses Pengolahan Susu Pasteurisasi menunjukkan susu pasteurisasi yang diproduksi oleh KUD Dau berpotensi mengandung Bahaya B. mengandung bahan tambahan makanan dan kandungan gizi dari susu. Bahaya D. Produk susu pasteurisasi kemungkinan dapat terkontaminasi ulang setelah pengolahan dan sebelum pengepakan. Bahaya E Pada susu pasteurisasi terdapat bahaya yang potensial pada penanganan saat distribusi atau penanganan oleh konsumen. Bahaya $\mathrm{F}$. Tidak ada proses pemanasan akhir setelah proses pengepakan atau ketika dimasak di rumah. Hasil penelitian ini menyimpulkan bahwa TKK pengolahan susu pasteurisasi adalah tahapan: penerimaan susu di pos penampungan, pasteurisasi tahap I dan homogenisasi, pasteurisasi tahap II, pencampuran flavour, penyimpanan serta distribusi.
\end{abstract}

Kata Kunci: KUD Dau, Pasteurisasi, Titik kontrol kritis

\section{Critical Control Point In Pasteurized Milk Processing in KUD Dau Malang District}

\section{ABSTRACT}

Research on Critical Control Point in Pasteurized Milk Processing in KUD Dau aims to analyze the critical control points on the processing of pasteurized milk using a decision tree in KUD Dau. The method used is descriptive method quantitative survey research approach. Population and sample are officers at the post shelter, the driver's vehicle fleet tanker, tank officers in transit, the officer in pasteurized milk processing and sanitation workers in KUD Dau, the number of samples is 22 people targeted research. The analysis technique used is descriptive statistical techniques. Results of research Critical Control Point Pasteurized Milk Processing showed pasteurized milk produced by KUD Dau potentially contain Hazards B. containing food additives and nutritional value of milk. Danger D. pasteurized milk products likely to be contaminated again after processing and prior to packing. E Danger In pasteurized milk there is a potential danger in handling during distribution or handling by consumers. Danger F. There is no end of the heating process after packing or when cooked at home. The results of this study concluded that CCPs are pasteurized milk processing stages: milk reception in the post shelter, pasteurization and homogenization phase I, phase II pasteurization, flavor blending, storage and distribution.

Keywords: Critical control point, KUD Dau, Pasteurization

\section{PENDAHULUAN}

Peternakan sapi perah di Indonesia, sebagian besar ditangani oleh koperasi persusuan. Implikasi dari tanggungjawab tersebut, maka proses pengolahan susu sebagian besar juga di proses oleh koperasi. Salah satu proses pengolahan susu yang dilakukan oleh koperasi adalah dengan membuat susu pasteurisasi. Proses pasteurisasi susu memiliki tahapan yang dapat mempengaruhi mutu produk akhir. Tahapan tersebut misalnya suhu pasteurisasi, sumber bahan baku dan penanganannya, serta penyimpanan dan distribusi. Sumber bahan baku utama susu pasteurisasi diperoleh dari peternak anggota koperasi, sehingga pengawasan mutu seharusnya sudah dilakukan mulai dari peternak (Murdiarti et al., 2004).

Pasteurisasi bertujuan untuk membunuh mikroba patogen, mikroba pembusuk dan menginaktifkan

*Penulis Korespondensi: N. D. Kristanti

Alamat: Jl. DR. Cipto 144a Bedali - Lawang, Malang

E-mail: novistpp.mlg@gmail.com enzim. Menurut Lejeune dan Rajala-Schultz, (2009), masa simpan susu dan produk susu dapat diperpanjang dengan pasteurisasi selain dapat menghancurkan sebagian mikroba dan meningkatkan keamanannya. Pasteurisasi mampu menghilangkan sebagian besar sel-sel vegetatif, akan tetapi beberapa spesies seperti mikroba termodurik, termofil dan beberapa mikroba berbentuk batang gram negatif masih dapat bertahan pada suhu pasteurisasi, sehingga berdampak pada keamanan kualitas produk susu.

Penelitian-penelitian telah dilakukan untuk memastikan keamanan produk makanan dengan menggunakan sistem Hazard Analysis Critical Control Point (HACCP). HACCP merupakan alat yang digunakan dalam industri makanan untuk mengidentifikasi, menilai dan mengendalikan bahaya, fokus pencegahan terjadi bahaya. HACCP dapat meningkatkan kualitas mikrobiologi es krim (Kokkinakis et al., 2008), dan udang beku (Nuryani, 2007). Alat yang tepat untuk menetapkan sistem pengendalian mutu adalah menggunakan sistem 
HACCP, karena berfokus pada pencegahan produk akhir. Seluruh rantai pangan dari produk primer sampai pada konsumsi akhir dapat menerapkan HACCP. Salah satu bagian penting dalam sistem HACCP adalah dengan penentuan titik kontrol kritis (TKK) (Hermansyah et al., 2013).

Konsumen beranggapan pengawasan mutu yang dilakukan pada pengawasan produk akhir saja belum dapat menjamin keamanan maupun kelayakan mutu makanan seutuhnya sesuai tuntutan konsumen. HACCP merupakan suatu sistem pengawasan mutu untuk industri pangan yang dapat menjamin keamanan pangan, yang dapat mencegah bahaya atau resiko yang mungkin timbul dan menetapkan pengawasan tertentu dalam usaha pengendalian mutu pada seluruh rantai produksi pangan. Dalam konsep jaminan mutu tersebut, bahan yang dapat membahayakan keselamatan manusia atau yang merugikan akan diidentifikasi dan diteliti. Demikian juga simpul atau titik dimana kemungkinan besar terjadi bahaya akan diidentifikasi, mulai dari penyediaan bahan baku, selama tahapan proses pengolahan hingga produk siap dikonsumsi (Crowther, 1996).

Evaluasi tahapan setiap titik kontrol kritis sebagai bagian pelaksanaan penjaminan mutu perlu dilakukan untuk mengetahui sejauh mana perubahan yang terjadi pada produk, sehingga dapat berpengaruh terhadap kualitas produk yang dihasilkan. Bertitik tolak pada evaluasi tiap tahapan TKK yang menekankan pada upaya pencegahan terjadinya hazard (bahaya) selama proses pengolahan susu pasteurisasi, maka perlu menginventarisasi kemungkinan timbulnya bahaya bagi konsumen, serta pengawasan terhadap titik-titik kritis dalam setiap tahapan proses. Berdasarkan latarbdlakang diatas maka tujuan penelitian ini adalah untuk menganalisis titik kontrol kritis (TKK) pada pengolahan susu pasteurisasi dengan menggunakan decision tree di Koperasi Unit Desa (KUD) Dau.

\section{MATERI DAN METODE}

Metode penelitian yang digunakan untuk mengetahui kelayakan proses pengolahan susu pasteurisasi adalah metode deskriptif kuantitatif dengan pendekatan penelitian survei untuk menggali data sehingga dapat memberikan pemahaman kepada objek penelitian (Idrus, 2009). Metode penentuan titik kontrol kritis (TKK) menggunakan decision tree. Lokasi pengambilan sampel adalah di industri pengolahan susu pasteurisasi di KUD Dau Malang. Proses pengolahan susu pasteurisasi di KUD Dau menggunakan alat pasteurisasi sistem plate heat exchanger (PHE). Pertimbangan pemilihan lokasi adalah jangkauan pemasaran susu pasteurisasi luas, jumlah produksi besar, sumber bahan baku susu berasal dari peternakan rakyat, dan belum dilaksanakan pengendalian mutu dengan konsep penentuan TKK dan batas kritis, sehingga perlu dilakukan pengkajian mutu dan keamanan produk.
Populasi pada penelitian ini adalah para petugas di pos penampungan, pengemudi kendaraan tangki armada, petugas di tangki transit, petugas pada pengolahan susu pasteurisasi dan petugas sanitasi di KUD Dau. Adapun jumlah total populasi penelitian adalah 22 orang. Metode pengambilan sampel yang digunakan adalah metode sensus (Idrus, 2009), yaitu seluruh anggota populasi dijadikan sampel penelitian, yaitu berjumlah 22 orang. Teknik pengumpulan data menggunakan metode angket tertutup dan observasi (Idrus, 2009). Angket tertutup merupakan jawaban responden dari pengamatan terhadap kegiatan mulai dari penerimaan bahan baku susu segar di pos penampungan sampai kegiatan di bagian distribusi susu pasteurisasi. Analisis data yang digunakan untuk melakukan penilaian kelayakan dasar proses produksi dan penilaian bangunan, fasilitas, sanitasi dan higienis menggunakan analisis statistik deskriptif kuantitatif yaitu untuk mendeskripsikan keadaan gejala sosial apa adanya (Winarno dan Surono, 2002). Penentuan pengambilan keputusan titik-titik kritis proses pengolahan susu pasteurisasi dianalisis menggunakan 'Decision Tree'. Decision tree merupakan suatu set alat pengambilan keputusan yang terdiri dari pertanyaan-pertanyaan untuk menentukan titik-titik kritis dalam suatu proses pengolahan bahan pangan.

\section{HASIL DAN PEMBAHASAN}

\section{Deskripsi Produk}

Produk yang dianalisis adalah susu pasteurisasi. Sumber bahan baku susu pasteurisasi, berupa susu segar diperoleh dari peternak anggota KUD. Adapun deskripsi produk susu pasteurisasi disajikan pada Tabel 1. Hasil pengamatan menunjukan pemberian label pada susu pasteurisasi yang diproduksi oleh KUD Dau masih kurang lengkap karena hanya mencantumkan nama produk, nama produsen, nomer ijin usaha dan tanggal kadaluwarsa. Berat bersih, persentase lemak, cara konsumsi, cara menyimpan, kondisi transportasi, prosedur perlakuan panas, dan kode produksi tidak dicantumkan dalam kemasan. Pedoman pemberian label sesuai panduan HACCP adalah dengan mencantumkan: nama produsen pada kemasan, nama produk, berat bersih, persentase lemak, cara konsumsi, cara menyimpan, kondisi transportasi, prosedur perlakuan panas, dan kode produksi (Winarno dan Surono, 2002).

Perbandingan karakteristik susu pasteurisasi antara produksi KUD Dau dengan standar SNI disajikan pada Tabel 2. Standar Internasional "FDA" untuk susu pasteurisasi telah diatur khusus di dalam "Pasteurized Milk Ordinance". Standar mikroba yaitu total bakteri maksimal $2 \times 10^{4} \mathrm{CFU} / \mathrm{ml}$, bakteri koliform maksimal 10 koloni dan kandungan fosfatase maksimal 350 milliunits/L (Anonymous, 1995). Hasil analisis menunjukan standar susu pasteurisasi yang diberlakukan di KUD Dau tidak berbeda dengan standar yang ditetapkan oleh SNI. 
Tabel 1. Deskripsi produk susu pasteurisasi produksi KUD Dau

\begin{tabular}{|c|c|c|}
\hline No & Parameter & Hasil Identifikasi (results Identification) \\
\hline 1. & $\begin{array}{l}\text { Nama produk } \\
\text { (Product name) }\end{array}$ & : Susu pasteurisasi \\
\hline 2. & Penggunaan produk & : Produk susu pasteurisasi siap konsumsi \\
\hline 3. & Karakteristik produk & $\begin{array}{l}\text { Fisik: bau, rasa dan kekentalan normal. } \\
\text { Kimia: kadar lemak minimal 3\%, Bj minimal 1.002\%, pH 6,4-6,7 } \\
\text { Mikroba: E.coli negative }\end{array}$ \\
\hline 4. & Kemasan & : cup dan botol jenis bahan Polietilen \\
\hline 5. & Masa penggunaan & : Maksimal 5 hari, disimpan pada suhu $2-4^{\circ} \mathrm{C}$ \\
\hline 6. & Pemasaran & : Menggunakan cooling box dan mobil box dengan pendingin. \\
\hline 7. & Labeling & : Merk “Dau Fresh Milk” \\
\hline 8. & Kandungan Gizi & : \\
\hline & - Kalori & $148 \mathrm{kkal}$ \\
\hline & - Kalori lemak & $59 \mathrm{kkal}$ \\
\hline & - $\quad$ Protein & $5,4 \mathrm{~g}$ \\
\hline & - $\quad$ Gula & $12,4 \mathrm{~g}$ \\
\hline & - Lemak & $5,9 \mathrm{~g}$ \\
\hline & - Karbohidrat & $15,9 \mathrm{~g}$ \\
\hline & - Vitamin & A, \\
\hline
\end{tabular}

Sumber: Data Primer dan Data Sekunder

Penilaian Kelayakan Dasar Proses Produksi

Hasil analisis deskriptif penilaian kelayakan dasar pengolahan susu pasteurisasi di KUD Dau disajikan dalam Tabel 3. Penilaian kelayakan dasar pengolahan susu pasteurisasi dilakukan oleh petugas yang bertanggung jawab menangani seluruh proses pengolahan susu pasteurisasi mulai dari pos penampungan, transportasi (tangki armada), bak penyimpanan, tangki transit, pada saat pengolahan pasteurisasi dan homogenisasi, pasteurisasi tahap ke II, pencampuran flavour, pengemasan dan penyimpanan dengan cara mengisi kuesioner dan

Tabel 2. Perbandingan karakteristik susu pasteurisasi

\begin{tabular}{|c|c|c|c|}
\hline No & Parameter & Standar KUD Dau & Standar SNI \\
\hline 1. & Uji organoleptik & Normal & $\begin{array}{l}\text { Tidak ada perubahan warna, bau, rasa dan } \\
\text { kekentalan* }\end{array}$ \\
\hline 2. & Uji alcohol & Normal & Alkohol 70\% negatif* \\
\hline 3. & Kadar lemak & Minimal $3.00 \%$ & Minimal 2,8 \%* \\
\hline 4. & Berat jenis & Minimal 1,024 \% & Minimal $1,0270 \mathrm{~g} / \mathrm{ml}^{*}$ \\
\hline 5. & $\mathrm{pH}$ & $6,4-6,7$ & $6,3-6,8^{*}$ \\
\hline 6. & Pemalsuan & Tidak ada & Tidak ada* \\
\hline 7. & TPC & - & $<3 \times 10^{4} \mathrm{CFU} / \mathrm{ml}^{*}$ \\
\hline 8. & Koliform & - & $<10(\mathrm{MPN} / \mathrm{ml})^{*}$ \\
\hline 9. & Fosfatase & - & $0^{*}$ \\
\hline 10. & Kadar protein minimal & - & $2,5 \% *$ \\
\hline 11. & BK tanpa lemak minimal & - & $7,5 \% *$ \\
\hline 13. & E. coli $(\mathrm{MPN} / \mathrm{g}$ atau $\mathrm{ml})$ & - & $0 * *$ \\
\hline 14. & Enterococi & - & $1 \times 10^{2} * *$ \\
\hline 15. & Staphylococcus aureus & - & $1 \times 10^{1} * *$ \\
\hline 16. & Clostridium $s p$ & - & $0 * *$ \\
\hline 17. & $\begin{array}{l}\text { Salmonella sp (dalam satuan } \\
\text { kualitatif) }\end{array}$ & - & Negatif $* *$ \\
\hline 18. & Camphylobacter $s p$ & - & $0 * *$ \\
\hline 19. & Listeria $s p$ & - & $0 * *$ \\
\hline
\end{tabular}

Keterangan: SNI adalah standar nasional Indonesia, *SNI (01-3951-1995) = standar susu pasteurisasi B (diberi penyedap cita rasa), **SNI 01-6366-2000 = Batas maksimal cemaran mikroba dan batas maksimal residu dalam bahan makanan asal hewan (susu pasteurisasi). 
wawancara secara terstruktur.

Hasil analisis menunjukkan bahwa pada pos penampungan, transportasi, dan pengemasan rata-rata responden menjawab masih kurang layak, sehingga tahapan di pos penampungan menjadi bahan evaluasi yang harus diperhatikan, adapun penjelasannya sebagai berikut:

Pos penampungan. Hasil analisis pada proses penampungan di pos penampungan, menunjukkan bahwa rata-rata menjawab tidak sesuai dengan standar yang telah ditentukan yaitu dengan nilai rata-rata sebesar 2,36 seperti yang tertera pada Tabel 3 .

Adapun hasil analisis menunjukkan bahwa sesaat setelah susu ditampung, susu tidak segera didinginkan. Penanganan susu segar dari tahap satu ke tahap selanjutnya tidak secara cepat, tidak menggunakan suhu yang rendah serta tidak higienis. Penanganan susu segar untuk menuju pos penampungan tidak didinginkan terlebih dahulu. Pendapat De Oliverira et al. (2011) bahwa sumber kontaminasi mikroba pada susu segar dapat bersumber dari sapi yang terkena mastitis, peternak atau pada saat pemerahan dan peralatan yang kurang higienis.

Transportasi (tangki armada). Hasil analisis pada proses transportasi menggunakan tangki armada, menunjukkan bahwa nilai rata-rata menjawab 2,33 dengan kriteria tidak sesuai berdasarkan standar yang telah ditentukan seperti yang ditunjukan pada Tabel 3 .

Adapun hasil analisis menunjukkan bahwa susu sesaat setelah ditampung, tidak segera didinginkan, penanganan bahan baku dari tahap satu ke tahap selanjutnya tidak secara cepat, tidak hati-hati pada suhu rendah serta tidak higienis sehingga suhu tidak sesuai, penanganan susu segar untuk menuju pos penampungan pusat tidak didinginkan atau dikumpulkan pada tangki yang higienis dan bersuhu rendah. Pendapat De Oliverira et al. (2011) bahwa sumber kontaminasi mikroba pada susu segar tidak selalu dari peternakan. Kemungkinan peningkatan jumlah mikroba adalah kontaminasi dari penanganan karyawan di pos penampungan yang kurang baik dan pada saat transportasi.

Bak penyimpanan dan tangki transit. Pada proses penyimpanan di bak penyimpanan dan tangki transit, hasil analisis menunjukkan bahwa responden menjawab proses penyimpanan dan dalam tangki transit sesuai dengan standar yang telah ditentukan yaitu; sesuai dengan standar SNI dengan nilai rata-rata
4,20 seperti yang ditunjukan pada Tabel 3 .

Penerimaan susu segar dari tangki armada dilakukan dengan cepat, higienis dan terlindung dari panas matahari, pengaruh panas, cuaca dan penularan kotoran. Segera setelah ditampung, susu didinginkan sehingga suhu susu segar berkisar antara 0 sampai $4^{\circ} \mathrm{C}$.

Penanganan bahan baku dari tahap yang satu ke tahap yang berikutnya, dilakukan secara cepat, hatihati pada suhu rendah serta higienis. Penanganan susu segar untuk menuju pos transit didinginkan atau dikumpulkan pada tangki yang higienis dan bersuhu rendah. Menurut Prejit et al. (2007), kontaminasi mikroba dapat diminimalkan apabila selama penanganan kesehatan pegawai dijaga dan pegawai mengikuti prosedur penanganan susu dengan baik.

Pengolahan. Hasil analisis dari wawancara dan kuesioner menunjukkan bahwa pada proses pengolahan sudah sesuai dengan standar yaitu dengan nilai rata-rata sebesar 3,75 seperti yang tertera pada tabel3. Namun hasil analisis mikrobiologi pada susu pasteurisasi di KUD Dau yang dilakukan sesaat setelah pasteurisasi menunjukkan bahwa masih terdapat sejumlah mikroba. Keberadaan bakteri menunjukkan bahwa proses pemanasan yang dilakukan tidak cukup untuk membunuh sel vegetatif. Bakteri yang tahan terhadap panas tetapi tidak harus tumbuh pada suhu panas disebut bakteri termodurik.

Kontaminasi bakteri termodurik diduga terjadi mulai dari proses penampungan susu segar sampai susu akan dikemas. Kemungkinan, bakteri termodurik masih dapat berkembang biak selama dalam proses pengolahan dan penyimpanan. Menurut Hassan et al. (2009), bakteri yang termasuk dalam golongan termodurik adalah golongan Streptococcus dan Lactobacillus dan kelompok yang lain. Jenis bakteri ini banyak ditemukan pada produk yang telah melalui proses pasteurisasi yaitu pada suhu $63^{\circ} \mathrm{C}$ selama 30 menit atau $72^{\circ} \mathrm{C}$ selama 15 detik. Micrococcus, Microbacterium, Streptococcus, Lactobacillus, Bacillus dan Clostridium adalah beberapa jenis bakteri termodurik dan Aspergillus dan Penicillium adalah jenis kapang yang mampu tumbuh pada suhu pasteurisasi. Ruegg and Reinemann (2002) menambahkan bahwa bakteri termodurik yang dapat tumbuh pada suhu pasteurisasi adalah Bacillus, Clostridium, Micrococcus, Microbacterium, Lactobacillus dan kadang-kadang juga terdapat

Tabel 3. Analisis deskriptif tahapan proses pasteurisasi

\begin{tabular}{lccccc}
\hline \hline \multicolumn{1}{c}{ Tahapan } & Jumlah Sampel & Minimal & Maksimal & Rata-rata & Kriteria \\
\hline Pos Penampungan & 9 & 2 & 3 & $2.36 \pm 0,26$ & Tidak sesuai \\
Transportasi & 9 & 2 & 3 & $2.33 \pm 0,40$ & Tidak sesuai \\
Bak Penyimpanan & 5 & 4 & 4 & $4.20 \pm 0,20$ & Sesuai \\
Tangki Transit & 5 & 3 & 4 & $3.64 \pm 0,33$ & Sesuai \\
Pasteurisasi + Homogenisasi & 8 & 3 & 4 & $3.87 \pm 0,35$ & Sesuai \\
Pasteurisasi tahap II & 8 & 3 & 4 & $3.75 \pm 0,43$ & Sesuai \\
Pencampuran Flavour & 8 & 3 & 4 & $3.34 \pm 0,19$ & Cukup sesuai \\
Pengemasan & 8 & 2 & 3 & $2.46 \pm 0,31$ & Tidak sesuai \\
Penyimpanan & 8 & 3 & 4 & $3.62 \pm 0,52$ & Sesuai
\end{tabular}


Tabel 4. Analisis deskriptif penilaian bangunan, fasilitas, sanitasi dan higienis

\begin{tabular}{lccccc}
\hline \multicolumn{1}{c}{ Lingkungan } & Jumlah Sampel & Minimal & Maksimal & Mean & Kriteria \\
\hline Lokasi Lingkungan & 10 & 3 & 5 & $3,70 \pm 0,48$ & Sesuai \\
Kontruksi Bangunan & 10 & 3 & 3 & $3,00 \pm 0,00$ & Cukup Sesuai \\
Penerangan & 10 & 4 & 5 & $4,70 \pm 0,48$ & Sangat Sesuai \\
Ventilasi & 10 & 4 & 5 & $4,40 \pm 0,52$ & Sesuai \\
Saluran pembuangan & 10 & 3 & 4 & $3,70 \pm 0,48$ & Sesuai \\
Pasokan Air & 10 & 4 & 5 & $4,60 \pm 0,52$ & Sangat Sesuai \\
Penanganan Limbah & 10 & 3 & 5 & $3,30 \pm 0,48$ & Cukup Sesuai \\
Toilet & 10 & 2 & 3 & $2,40 \pm 0,52$ & Tidak Sesuai \\
Kontruksi dan Pemeliharaan & 10 & 4 & 5 & $4,20 \pm 0,42$ & Sesuai \\
alat & & & & & Sesuai \\
Pembersihan dan sanitasi & 10 & 3 & 4 & $3,50 \pm 0,52$ & Sesuai \\
Kontrol sanitasi & 10 & 4 & 5 & $4,40 \pm 0,52$ & Sesuai \\
Serangga, tikus, Burung dll & 10 & 3 & 5 & $4,30 \pm 0,67$ & Cukup sesuai \\
Bahan-bahan Kimia & 10 & 3 & 3 & $3,00 \pm 0,00$ & \\
Total Responden & 10 & & & & \\
\hline
\end{tabular}

\section{Streptococcus.}

Pengemasan. Hasil analisis menujukkan bahwa, responden rata-rata menjawab pada saat pengemasan antara tidak sesuai sampai cukup sesuai dengan nilai rata-rata sebesar 3,62 seperti pada Tabel 3. Hal yang masih tidak sesuai adalah label pada produk akhir hanya memuat berat bersih dan nama produk, seharusnya pada label memuat jenis produk, berat bersih, nama bahan tambahan makanan yang dipakai, kode produksi, cara penyajian, cara penyimpanan, kandungan gizi, masa kadaluarsa dan persyaratan lainnya.

Pengemasan susu pasteurisasi menggunakan bahan pengemas gelas plastik $220 \mathrm{cc}$ dan botol plastik untuk kemasan 1 liter. Bahan pengemas yang digunakan berbahan dasar polietilen kategori food grade. Pengemasan susu pasteurisasi berfungsi sebagai: wadah untuk memuat produk, memelihara kesegaran dan kemantapan produk selama penyimpanan dan distribusi, melindungi bahan produk dari kontaminasi. Menurut Prejit et al. (2007), peralatan pengemasan dan bahan kemasan berkontribusi dalam mengkontaminasi susu pasteurisasi. Mikroba yang mengkontaminasi antara lain koliform dan kelompok Staphylococcus fekal.

\section{Penilaian Bangunan, Fasilitas, Sanitasi dan Higienis}

Penilaian terhadap kebersihan bangunan, fasilitas, sanitasi dan higienis produk meliputi: lokasi dan lingkungan, kontruksi bangunan, penerangan, ventilasi, saluran pembuangan, pasokan air, penanganan limbah, toilet, konstruksi dan pemeliharaan peralatan dan wadah, pembersihan dan sanitasi, kontrol sanitasi, serangga atau hewan, dan bahan-bahan kimia. Responden diminta untuk menilai sejauhmana penilaian tersebut sesuai dengan standar yang telah ditetapkan. Adapun hasil analisis dari jawaban responden disajikan dalam Tabel 4.

Hasil analisis menunjukan bahwa penilaian responden terhadap kriteria penilaian bangunan, fasilitas, sanitasi dan higienis menjawab antara cukup sesuai sampai sangat sesuai. Hal ini menunjukkan bahwa KUD Dau sudah berusaha secara maksimal untuk memenuhi standar pendirian industri pengolahan susu.

Sanitasi merupakan bagian yang penting untuk menjamin keamanan produk pangan. Sanitasi yang tidak efektif dapat menyebabkan kerusakan yang lebih parah pada produk makanan, dan dapat berdampak pada timbulnya penyakit apabila terkontaminasi mikroba patogen. Kesalahan dalam memilih bahan sanitasi dapat menimbulkan bahaya pada produk pangan, biaya mahal dan tidak efektif dalam penerapa sanitasi. Bahan kimia yang digunakan dalam proses sanitasi harus sesuai dengan rekomendasi (Anonymous, 2014). Menurut Vilkova et al., (2008), keefektifan penerapan sanitasi dipengaruhi oleh jenis bahan sanitasi, peralatan sanitasi yang digunakan, suhu, lama sanitasi, kesalahan air, karakteristik kontaminan, mikrotopografi permukaan, metode penerapan sanitasi, kemampuan bahan sanitasi mengikat kontaminan, dan kemampuan untuk menekan struktur biofilm.

Tabel 5. Tabulasi TKK menggunakan decision tree

\begin{tabular}{lccccc}
\hline Tahapan & Q1 & Q2 & Q3 & Q4 & $\begin{array}{c}\text { TKK/Bukan } \\
\text { TKK }\end{array}$ \\
\hline Penerimaan susu di pos penampungan & Ya & Tidak & Ya & Tidak & TKK \\
Pasteurisasi dan homogenisasi & Ya & Ya & - & - & TKK \\
Pasteurisasi tahap II & Ya & Ya & Ya & Tidak & TKK \\
Mix flavor & Ya & Tidak & Ya & Tidak & TKK \\
Penyimpanan produk & Ya & Tidak & Ya & Tidak & TKK \\
Distribusi produk & Ya & Ya & - & - & TKK \\
\hline
\end{tabular}


Sanitasi mesin dan peralatan adalah usaha untuk membunuh sebagian besar atau seluruh mikroba yang terdapat pada seluruh mesin atau alat. Peralatan yang dipakai dalam proses produksi dapat meliputi alat-alat pemindahan bahan, alat tempat bahan mengalami perubahan dan penyesuaian dari alat tersebut. Sanitasi meliputi pencucian peralatan yang sempurna sehigga proses sanitasi alat dapat menghasilkan hasil yang diinginkan (tidak ada kontaminasi bakteri dari alat ke dalam susu segar). Apabila peralatan belum bersih, maka proses sanitasi tidak akan efektif yang berdampak pada tingginya kontaminasi mikroorganisme pada susu segar (Anonymous, 2004).

\section{Penentuan Titik Kontrol Kritis (TKK) Proses Pengolahan Susu Pasteurisasi}

Penentuan TKK dalam proses pengolahan susu pasteurisasi di KUD Dau dilakukan dengan menggunakan metode Decision Tree yang merupakan suatu set alat pengambilan keputusan yang terdiri dari pertanyaan-pertanyaan untuk menentukan titik-titik kritis dalam suatu proses pengolahan bahan pangan. Secara tabulasi, kondisi tahapan proses pengolahan susu pasteurisasi di KUD Dau, berdasarkan hasil pengamatan dan observasi yang dilakukan serta hasil pengolahan data menggunakan Decision Tree seperti disajikan pada Tabel 5 .

Menurut Prejit et al. (2007), TKK pada proses pengolahan susu pasteurisasi adalah: susu segar dari peternak, penampungan susu, pendinginan susu, pasteurisasi, pengemasan dan penyimpanan susu. Menurut Sudarmaji (2005), penggolongan karakteristik bahaya dikelompokkan menjadi (1) Bahaya A: merupakan kelompok yang dapat menyebabkan produk yang didesain dan ditujukan untuk kelompok berisiko (bayi, lanjut usia, orang sakit, ataupun orang dengan daya tahan tubuh rendah) menjadi tidak steril, (2) Bahaya B: produk mengandung bahan yang sensitif terhadap bahaya mikrobiologis, (3) Bahaya C: proses yang dilakukan tidak diikuti dengan langkah pengendalian yang efektif untuk merusak mikroba yang berbahaya, (4) Bahaya D: produk terkontaminasi ulang setelah pengolahan dan sebelum pengepakan, (5) Bahaya E: terdapat bahaya yang potensial pada penanganan saat distribusi atau penanganan oleh konsumen sehingga menyebabkan produk berbahaya jika dikonsumsi, dan (6) Bahaya F: tidak ada proses pemanasan akhir setelah proses pengepakan atau ketika dimasak di rumah.

Hasil tabulasi menunjukkan bahwa susu pasteurisasi yang diproduksi oleh KUD Dau berpotensi mengandung (1) Bahaya B. Produk susu pasteurisasi kemungkinan mengandung bahan yang sensitif terhadap bahaya mikrobiologis, antara lain: dari bahan tambahan makanan dan kandungan gizi dari susu, (2) Bahaya D. Produk susu pasteurisasi kemungkinan dapat terkontaminasi ulang setelah pengolahan dan sebelum pengepakan. Rekontaminasi juga kemungkinan berasal dari peralatan untuk pengolahan, (3) Bahaya E. Pada susu pasteurisasi terdapat bahaya yang potensial pada penanganan saat distribusi atau penanganan oleh konsumen sehingga menyebabkan produk berbahaya jika dikonsumsi. Hal ini dapat terjadi apabila pada saat distribusi dan penyimpanan tidak dilakukan kontrol terhadap suhu, baik selama distribusi maupun selama penyimpanan. Kemungkinan spora bakteri maupun bakteri termodurik yang masih bertahan dapat berkembang saat distribusi dan penyimpanan, dan (4) Bahaya F. Tidak ada proses pemanasan akhir setelah proses pengepakan atau ketika dimasak di rumah. Susu pasteurisasi merupakan produk yang disimpan dalam suhu dingin, dan tidak perlu dilakukan pemanasan ulang sebelum dikonsumsi.

\section{KESIMPULAN}

Hasil penelitian ini menyimpulkan bahwa hasil penentuan TKK pengolahan susu pasteurisasi dengan menggunakan metode kuantitatif adalah tahapan: penerimaan susu di pos penampungan, pasteurisasi tahap I dan homogenisasi, pasteurisasi tahap II, pencampuran flavour, penyimpanan serta distribusi. Berdasarkan hasil penelitian ini, diharapkan dapat menjadi bahan edukasi bagi pengelola industri pengolahan susu pasteurisasi, khususnya di industri kelas menengah ke bawah seperti koperasi persusuan yang terdapat di Kota Malang, Jawa Timur.

\section{DAFTAR PUSTAKA}

Anonymous. 1995. Susu Pasteurisasi. SNI 01-39511995. Standar Nasional Indonesia. Badan Standardisasi Nasional.

Anonymous. 2004. Codex Alimentarius Comission Cac/Rcp 57-2004 : Code of Hygienic Practice For Milk and Milk Products. Fao and Who, Rome.

Anonymous. 2014. Dairy Processing Plants: Guidelines for the Cleaning of Dairy Plant Processing Equipment. Bc Centre for Disease Control.

http://www.bccdc.ca/nr/rdonlyres/bf40bb536264-48ad-

8a25a09f43b5caf0/0/dairyprocessingcleaning. Diunduh Tanggal 9 Maret 2015.

Crowther. J. 1996. HACCP module training. Pros. Seminar Sehari Pengamanan Hasil Peternakan untuk Meningkatkan Daya Saing Pasar. Jakarta, Januari 1996

Hassan, N. B. A., M. O. M. Abdalla. and A. A. A. M. Nour. 2009. Microbiology Quality of HeatTreated Milk During Storage. Pakistan Journal of Nutrition 8(12): 1845-1848.

Hermansyah, M., Pratiko., R, Soenoko.,dan N.W. Setyanto. 2013. Hazard Analysis and Critical Control Point (HACCP) Produksi Maltosa dengan Pendekatan Good Manufacturing 
Practice (GMP). Journal of Engineering and Management in Industrial System 1(1): 14-20.

Idrus, M. 2009. Metode Penelitian Ilmu Sosial Pendekatan Kualitatif dan Kuantitatif. Gelora Aksara Pratama. Yogyakarta.

Kokkinakis, E. N., G. A. Fragkiadakis, S. H. Loakeimidi, I. B. Giankoulof and A. H. Kokkonak. 2008. Microbiological Quality of Ice Cream After HACCP Implementation: A Factory Case Study. Czech Journal of Food Science 26(5): 383-391.

Lejeune, J. T. and P. J. Rajala-Schultz. 2009. Unpasteurized Milk: A Continued Public Health Threat. Oxford Journals. Medecine. Clinical Infectious Diseases 48(1): 93-100.

Murdiarti, T.B. A, Priadi., S,Rachmawati, dan Yuningsih.2004. Susu Pasteurisasi dan Penerapan HACCP (Hazard Analysis Critical Control Point). Jurnal Ilmu Ternak dan Veteriner 9(3): 172-180.

Nuryani, A. B., Y. S. Darmanto. dan T. W. Agustini. 2007. Pengendalian Mutu Penanganan Udang Beku dengan Konsep Hazard Analysis Critical Control Point (Studi Kasus di Kota Semarang dan Kabupaten Cilacap). Jurnal Pasir Laut 3(1): 19-26.

Prejit, E. Nanu. and C. Latha. 2007. Microbial Quality Assurance of Milk

During Production, Processing and Marketing. American Journal of Food Technology 2(3): 136144.

Ruegg, P. L. and D. J. Reinemann, 2002. Milk quality and mastitis test. University of Wisconsin Extension Services. The Bovine Practice, 36,113 .

Sudarmaji. 2005. Analisis Bahaya dan Pengendalian Titik Kritis (Hazard Analysis Critical Control Point). Jurnal Kesehatan Lingkungan 1(2): 183190.

Vlkova, H., V. Babak, R. Seydlova, I. Pavlik. and J. Schlegelova. 2008. Biofilms and Hygiene on Dairy Farms and in the Dairy Industry: Sanitation Chemical Products and Their Effectiveness on Biofils- A Review. Czech Journal of Food Science 26(5): 309- 323.

Winarno, F. G. dan Surono.2002. HACCP dan Penerapannya dalam Industri Pangan. M-Brio Press. Bogor. 